\title{
ПРОБЛЕМА ПОШИРЕННЯ ТОКСИКАНТІВ У ТВАРИННИЦТВІ І ДОВКІЛЛІ
}

\author{
Кобиш Антоніна Іванівна \\ кандидат ветеринарних наук, доцент \\ Державний науково-дослідний інститут з лабораторної діагностики
} та ветеринарно-санітарної експертизи, м. Київ, Україна

ORCID: 0000-0001-9372-5016 an.kobish@gmail.com

Чечет Ольга Миколаївна

кандидат ветеринарних наук

Державний науково-дослідний інститут з лабораторної діагностики та ветеринарно-санітарної експертизи, м. Київ, Україна

ORCID: 0000-0001-5099-5577

o.chechet@vetlabresearch.gov.ua

Шуляк Світлана Валеріївна

кандидат ветеринарних наук

Державний науково-дослідний інститут з лабораторної діагностики та ветеринарно-санітарної експертизи, м. Київ, Україна

ORCID: 0000-0001-8501-1750 dia_sveta_@ukr.net

Омельчун Юлія Анатоліївна

Державний науково-дослідний інститут з лабораторної діагностики та ветеринарно-санітарної експертизи, м. Київ, Україна

ORCID: 0000-0001-8895-7250 my_answer@ukr.net

Мягка Катерина Сергіївна кандидат ветеринарних наук Державний науково-дослідний інститут з лабораторної діагностики та ветеринарно-санітарної експертизи, м. Київ, Україна

ORCID: 0000-0002-3089-4012

katerina_miagka@meta.ua

Марченко Таїса Володимирівна

Державний науково-дослідний інститут з лабораторної діагностики та ветеринарно-санітарної експертизи, м. Київ, Україна

ORCID: 0000-0001-8993-2936

taya.marchenko@ukr.net

Лінійчук Наталія Василівна

кандидат ветеринарних наук

Державний науково-дослідний інститут з лабораторної діагностики та ветеринарно-санітарної експертизи, м. Київ, Україна ORCID: 0000-0001-6745-307X galkanat@ukr.net

Значне розширення масштабів синтезу і застосування у сільському господарстві різних небезпечних хімічних сполук спричинює щоденний небезпечний вплив на організм комах, тварин i, безперечно, людини. Саме тому виникає потреба у контролі за поширенням токсикантів хімічної і біологічної природи у тваринництві і довкіллі. Нами проведено аналіз поширення токсикантів у тваринництві і довкіллі шляхом хіміко-токсикологічного аналізу кормів, посліду, крові, внутрішніх органів, умісту шлунку загиблих від отруєння тварин, а також загиблих бджіл, грунту, зеленої маси і продуктів бджільниитва. У роботі застосовувалися сучасні методи досліджень. Уміст важких металів визначено методом атомно-абсорбційної спектрометрії, пестицидів - методом газової хроматографрії і рідинної хромато-мас-спектрометрії, мікотоксинів - методом високоефективної рідинної хроматографрії, імуноферментного аналізу і тонкошарової хроматографрії. Ізоніазид досліджено у шлунку собак методом рідинної хроматографрії 
із мас-спектрометричним детектором. Аналіз складу важких металів у біологічному матеріалі загиблих тварин показав, що частіше зустрічаються харчові отруєння їх миш'яком. Окрім того, зареєстровано значну частку отруєнь собак ізоніазидом. Установлено, що продукти бджільництва досить часто контамінуються пестицидами. Досліджено, що кукурудза, порівняно з іншими злаковими, частіше вражається мікроміцетами poду Aspergillus flavus i Fusarium. У кормах найчастіше виявлялися такі мікотоксини, як дезоксиніваленол, Т-2 токсин і зеараленон, рідше асрлатоксини. Таким чином, токсичне навантаження на екосистему призводить до порушення безпеки харчового ланцюга і зниження ефективності виробництва продукції тваринництва. Контамінація токсикантами кормів, а також медоносних рослин становить загрозу не тільки для сільськогосподарських тварин і корисних комах, але і для споживачів тваринницької продукції. Тому на національному і міжнародному рівнях дуже важливим є здійснення ефективного контролю за виробництвом та імпортом безпечних кормів і харчових продуктів.

Ключові слова: токсиканти, важкі метали, пестициди, мікотоксини, ізоніазид, екосистема, отруєння тварин, корми, продукти бджільництва.

DOI https://doi.org/10.32845/bsnau.vet.2021.3.3

Вступ. Питання про небезпечний антропогенний вплив на екосистему нині є, без сумніву, актуальним. Досить часто господарська діяльність людини призводить до забруднення довкілля ксенобіотиками. Це, у свою чергу, спричинює щоденний токсичний вплив на організм комах, тварин і, безперечно, людини.

Небезпечними для біотичних спільнот є забруднення довкілля важкими металами, а також хлорорганічними похідними. Ці екотоксиканти дуже стійкі до впливу факторів зовнішнього середовища і, відповідно, мають високу персистентність, тому можуть долати довгі харчові ланцюжки і зберігатись у природних об'єктах протягом багатьох років (Islam et al., 2007). Вони здатні призводити до порушення біологічних процесів у мікробіоценозах ґрунту і водойм. Основні ланки циркуляції токсичних речовин це атмосфера, ґрунт, водойми, рослини, тварини. Вони потрапляють у живі організми із повітрям, водою та їжею (Socorro et al., 2016; Chiaia-Hernandez et al., 2017; Zhou et al., 2020). Здатність токсикантів до кумуляції спричинює порушення біохімічних, цитологічних і фрізіологічних процесів, призводить до інтоксикацій, патології і навіть загибелі та загалом погіршує стан здоров'я і відтворюваність популяції живих організмів (Balali-Mood et al., 2021; Zhu et al., 2018; El-Nahhal, 2020).

Особливістю важких металів $€$ те, що вони здатні накопичуватись у кістках і заміщати корисні мінеральні елементи, такі як магній, кальцій та інші (Todorovic et al., 2008). Окрім того, небезпека важких металів полягає ще в тому, що більшість із них є надзвичайно токсичними навіть у мінімальній кількості (Mandal, 2017; Mulware, 2020).

Джерелом важких металів (наприклад ртуті і свинцю) $€$ промислові викиди та бензин (Mandal, 2017; Balali-Mood et al., 2021; Wu et al., 2021). Ртуть, кадмій і свинець містяться у будівельних матеріалах, батарейках та акумулятоpax. За даними екологів, основна частка всього свинцю, що циркулює в атмосфері, поповнюється за рахунок вихлопних газів (Zhou et al., 2020; More et al., 2017).

Велику загрозу для біосистеми несуть пестициди, які відносять до глобальних негативних чинників у природі. Вони негативно впливають на здоров'я тварин і комах як прямо, так і внаслідок накопичення залишкових кількостей у воді та кормах. До того ж наявність їх у поверхневих і ґрунтових водах перешкоджає відновленню родючості та зменшує харчові цінності сільськогосподарської продукції.

Слід зазначити, що стабільність агрохімікатів у ґрунті залежить від низки процесів, здатних зменшити їхній уміст. До таких процесів належать: біохімічне руйнування препаратів і перехід їх у рослини, фотохімічне руйнування, поглинання і трансформація ґрунтовими організмами, перехід у поверхневі та ґрунтові води, випаровування в атмосферу (Socorro et al., 2016; ChiaiaHernandez et al., 2017).

Нераціональне використання пестицидів у сільському господарстві викликає неабияке занепокоєння. Останнім часом велику увагу приділено руйнівній їх дії на корисних комах, особливо бджіл, оскільки сучасні інсектициди спричинюють гостру токсичність за менших доз порівняно із тими, що застосовувалися раніше. Контамінація бджіл відбувається як контактно, так і через пилок, нектар і воду. Найчастіше бджоли отруюються у весняно-літній період під час масового оброблення посівів і садів (Heard et al., 2017; Johnson et al., 2010; Pettis et al., 2013).

До небезпечних токсикантів віднесено також мікотоксини, введені у перелік регламентованих речовин у харчових продуктах, кормах і сировині. Вони здатні спричинювати мікотоксикози сільськогосподарських тварин і людини. Кумуляція їх в організмі супроводжується мутагенною, тератогенною, нейротоксичною, канцерогенною та імуносупресивною дією. Мітотоксини здатні порушувати білковий, ліпідний і мінеральний обмін речовин і спричинювати регресію органів імунної системи (GruberDorninger et al., 2019; Conte et al., 2020; Yang et al., 2020).

Мікотоксини утворюються під час життєдіяльності цілої низки мікроскопічних пліснявих грибів, серед яких вирізняють близько 350 видів, що продукують більше 300 токсинів. Слід зауважити, що практичне значення для сільського господарства і харчової промисловості мають близько 20 мікроміцетів. Їхні токсини досить стабільні, витримуючи кип'ятіння, оброблення кислотами та лугами. Потенційний ризик небезпечного впливу мікотоксинів на організм досить високий і залежить від виду токсину та виду тварин (Conte et al., 2020).

Найпоширенішими і небезпечними для здоров'я людини і тварин $є$ афлатоксини $\left(\mathrm{B}_{1}, \mathrm{~B}_{2}, \mathrm{G}_{1}, \mathrm{G}_{2}\right.$ та $\left.\mathrm{M}_{1}\right)$ продукти життєдіяльності Aspergillus flavus та Aspergillus parasiticus. Афрлотоксин є похідним кумарину, має виражені канцерогенні властивості, характеризується дуже високою токсичністю та викликає гостру інтоксикацію у тварин, що супроводжується високою смертністю. Молоді тварини страждають від дії токсинів значно більше, ніж дорослі. Перебіг афлотоксикозу ускладню- 
ється безпосереднім впливом на печінку, а також спостерігаються ураження інших органів - серця, нирок, селезінки. Крім того, мікотоксини здатні виділятись із молоком (Battilani et al., 2016).

До найнебезпечніших природних мікотоксинів, які виявляють у кукурудзі, ячмені і пшениці, відносяться: Т-2 токсин, ніваленол, дезоксиніваленол (вомітокин), диацетоксискарпенол. Останній належить до групи трихотеценових мікотоксинів - це більше 40-ка близьких за структурою сесквітерпеноїдів. Трихотецени здатні спричинювати гостру інтоксикацію, що характеризується ураженням нервової системи, всіх відділів травного тракту, геморагічним синдромом і виразками (Yang et al., 2020).

Продуцентами цієї групи токсинів є гриби роду Fusarium, Trichothecium, Mizothecium. Мікроміцети роду Fusarium синтезують також зеараленон і фумонізин.

У природних умовах зернові продукти одночасно із дезоксиніваленолом та Т-2 токсином контамінуються зеараленоном. Найчастіше його виявляють у кукурудзі. Він має сильну естрогенну і тератогенну дію, а також несе серйозну загрозу для тваринництва багатьох країн світу. Мікотоксин накопичується у тканинах тварин і здатний впливати на статеві органи. 3 організму метаболіти виділяються із жовчю, фекаліями і сечею. У лактуючих тварин метаболіти і сам токсин виділяються з молоком. Найбільш чутливими до токсину є свинки у віці 2-5 місяців, які утримуються у закритому приміщенні на комбікормах, збіднених вітамінами і легко засвоюваними вуглеводами. Введення у раціон зеленої маси знижує чутливість свиней до зеараленону. Підсисні поросята до 1 місяця і дорослі свиноматки вважаються більш стійкими до зеараленону. ЛД 50 зеараленона для морських свинок становить 5000 мг/кг, для білих пацюків - 10000 мг/кг, для курчат - більше 15000 мг/кг (Gruber-Dorninger et al., 2020).

На здоров'я тварин, птиці та людини можуть впливати такі мікотоксини, як охратоксини і патулін. Їх синтезують гриби роду Aspergillus і Penicillium. Найчастіше корми і харчові продукти контамінуються охратоксином $A$, рідше - охратоксином В. Відомо, що охратоксин А здатний зв'язуватися з альбумінами крові та локалізується переважно у нирках, печінці, міокарді та жировій тканині. Сироваткові альбуміни крові свині мають спорідненість до охратоксину A, тому найчастіше спричинюють нефропатії саме у свиней (Paterson \& Lima, 2010).

Патулін не має високу токсичність, але він $є$ генотоксичним. Через це виникли теорії щодо його канцерогенності. Патулін $є$ антибіотиком. Його зазвичай виявляють в яблуках, що гниють. Кількість патуліну може розглядатись як показник якості яблук. Деякі країни навіть установили патулінове обмеження в яблучних продуктах (Paterson \& Lima 2010).

Фумонізини зазвичай зустрічаються у кормах разом із іншими мікотоксинами, наприклад, афлатоксином, вомітоксином, охратоксином А, зеараленоном. Фумонізини контамінують переважно кукурудзу. Найбільш токсичним $€$ фумонізин В В організмі тварин вони вражають нирки та печінку. У птиці спричинюють рухові розлади і затримку росту. Більше того, існують відомості про те, що фумонізин пригнічує імунну систему, чинить тератогенну і канцерогенну дію (Yang et al., 2020; Gruber-Dorninger et al., 2020).

Окрім того, токсичну дію на живі організми за певних умов можуть мати ветеринарні препарати, наприклад, трапляється отруєння собак протитуберкульозним препаратом ізоніазидом, яке реєструється найчастіше порівняно з іншими отруєннями (Kotsiumbas \& Vretsona, 2019; Haburjak \& Spangler, 2002).

Метою нашої роботи є аналіз поширення токсикантів у тваринництві і довкіллі шляхом хіміко-токсикологічного аналізу кормів, посліду, крові, внутрішніх органів, умісту шлунку загиблих від отруєння тварин, а також загиблих бджіл, ґрунту, зеленої маси і продуктів бджільництва.

Матеріал і методи досліджень. Випробування проводились у науково-дослідному хіміко-токсикологічному відділі Державного науково-дослідного інституту з лабораторної діагностики та ветеринарно-санітарної експертизи впродовж 2015-2021 рр.

Об’єктом дослідження були корми, послід, кров, внутрішні органи, вміст шлунку загиблих від отруєння тварин, а також загиблі бджоли, ґрунт, зелена маса і продукти бджільництва, що можуть містити токсикант.

У роботі застосовано такі наукові методи досліджень: теоретичний пошук, аналіз і синтез, узагальнення, статистична обробка і порівняльний аналіз статистичних даних.

Головне завдання лабораторної діагностики отруєнь тварин - установити причину, тобто ідентифікувати токсикант. Для цього потрібно провести хіміко-токсикологічний аналіз, в основі якого лежить комплекс біологічних, фрізичних, хімічних та фрізико-хімічних методів дослідження ветеринарних об'єктів.

Суттєвим етапом хіміко-токсикологічного аналізу об'єктів ветеринарної медицини є відбір патологічного матеріалу, крові від хворих і загиблих тварин, бджіл, кормів, ґрунту, адже дотримання вимог до відбору проб для лабораторних випробувань впливає на достовірність кінцевого результату досліджень.

Випробувальний центр Державного науководослідного інституту з лабораторної діагностики та ветеринарно-санітарної експертизи акредитований відповідно до вимог ДСТУ ISO/IEC 17025:2017 Національним агентством із акредитації України. Тому у роботі центру застосовуються найсучасніші методики досліджень, проводиться їхня валідація і розробляються процедури випробувань.

За останні 7 років нами досліджено 48008 проб на вміст таких аналітів, як важкі метали, пестициди, мікотоксини і ветеринарні препарати (ізоніазид). Дослідження проведені згідно із внутрішніми процедурами випробувань. Важкі метали визначали методом атомно-абсорбційної спектрометрії, пестициди - методом газової хроматограсфії і рідинної хромато-мас-спектрометрії, мікотоксини - методом високоефективної рідинної хроматографії, імуноферментного аналізу і тонкошарової хроматографії. Ізоніазид досліджували у шлунку собак методом рідинної хроматографії із мас-спектрометричним детектором.

Результати досліджень. Із метою підтримання екологічної безпеки дуже важливо виявляти і контролювати 
джерела токсикантів в екосистемі, особливо у харчових ланцюгах.

Нами проведено дослідження наявності у ветеринарних об'єктах токсикантів, які є загрозою для живих організмів. У таблиці представлені статистичні показники загальної кількості проведених аналізів умісту токсикантів та кількості позитивних результатів за останні 7 років (табл. 1).

Серед важких металів ми визначали арсен, ртуть, кадмій, свинець. Вони потрапляють в організм живих істот із навколишнього середовища із їжею, водою і повітрям. Як свідчать статистичні відомості, найчастіше зустрічаються саме харчові отруєння тварин. Провівши аналіз загальної кількості досліджень умісту токсичних елементів за період 2015-2021 рр., ми встановили випадки отруєння тварин миш'яком. Зокрема, у 2015 році дослідженням патологічного матеріалу черепахи серед перерахованих токсичних елементів установлено позитивний результат за вмістом миш'яку. Крім того, у 2018 році зареєстровано позитивний результат випробувань за вмістом арсену у патологічному матеріалі кошеня.

Сучасне вирощування сільськогосподарських культур супроводжується застосуванням засобів захисту рослин, які відносяться до отруйних хімічних сполук і становлять загрозу для біосистеми. Нами проаналізовані продукти бджільництва, загиблі бджоли, ґрунт і зелена маса за вмістом гербіцидів, фунгіцидів та інсектицидів. До досліджуваних аналітів відносились ацетаміприд, альфа-циперметрин, циперметрин, перметрин, карбендазим, клотіанідин, тіаклоприд, імідаклоприд, тіаметоксам, тебуконазол, ципроконазол, лямбда-цигалотрин, фосмет, фрлутріафос, хлорпірифос, ацетохлор, диметоат. Окрім того, аналізували родентициди, такі як зоокумарин та бромадіалон, у внутрішніх органах і крові дрібних тварин. Загалом за останні 7 років ми провели 2619 випробувань на вміст пестицидів. Унаслідок випробувань ми отримали 188 позитивних результатів, що становить 7,2\% від загальної кількості. У 2015 році загальна кількість досліджень становила 94, із них пози- тивних результатів - 6, що у відсотковому відношенні становить 6,4\% (рис. 1, 2). Протягом 2021 року виконано у 60 разів більше досліджень (5675 аналізів), ніж у 2015 році, із них позитивних було 64, їхня частка від загальної кількості становить 1,1\%. Таке значне зростання виконаних випробувань пояснюється тим, що із 2020 року був розширений перелік аналітів за рахунок уведення в роботу нової методики - рідинної хромато-мас-спектрометрії. До 2020 року випробування здійснювалися за допомогою газової і тонкошарової хроматографії. Унаслідок збільшення кількості досліджуваних показників в одній пробі частка позитивних результатів значно знизилась. Але, якщо рахувати кількість позитивних проб серед загальної кількості проб, які аналізуються, то частка перших зросла в рази. Зокрема, у 2021 році досліджено 72 проби, із них у 64 установлена наявність пестицидів, причому частка таких проб становила $88 \%$.

Що стосується кількісних показників умісту пестицидів у досліджуваних пробах, то слід зазначити, що вони коливалися від рівня чутливості методу (0,001 мг/кг) і в окремих випадках досягали досить високих рівнів 1,463 мг/кг. Найчастіше реєстрували наявність інсектицидів, рідше - гербіцидів і фунгіцидів. Окрім того, встановлено, що тріазоли, які є фунгіцидами, разом із інсектицидами набувають високої токсичності та спричинюють загибель комах.

Слід зауважити, що корми для сільськогосподарських тварин здебільшого представлені рослинними продуктами, які часто вражаються мікотоксинами. Водночас ураження рослин грибками може відбуватись як під час дозрівання і збирання врожаю (тобто ще на полі у разі виникнення несприятливих метеорологічних умов), так і під час зберігання внаслідок порушення відповідних режимів.

Нами досліджувалися корми за вмістом найпоширеніших мікотоксинів, які мають практичне значення для аграрно-продовольчої безпеки, а саме афратоксин $\mathrm{B}_{1}$ афрлатоксин $\mathrm{M}_{1}$ сума афрлатоксинів, Т-2 токсин, зеараленон, фрумонізин, дезоксиніваленол, охратоксин А, патулін.

Таблиця 1

Статистичний аналіз кількості проведених аналізів умісту токсикантів у ветеринарних об'єктах та кількості позитивних результатів (2015-2021рр.)

\begin{tabular}{|c|c|c|c|c|c|c|c|c|c|c|c|c|c|c|}
\hline \multirow[b]{3}{*}{ Показник } & \multicolumn{14}{|c|}{ Рік проведення досліджень } \\
\hline & \multicolumn{2}{|c|}{2021} & \multicolumn{2}{|c|}{2020} & \multicolumn{2}{|c|}{2019} & \multicolumn{2}{|c|}{2018} & \multicolumn{2}{|c|}{2017} & \multicolumn{2}{|c|}{2016} & \multicolumn{2}{|c|}{2015} \\
\hline & 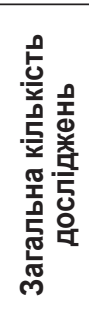 & 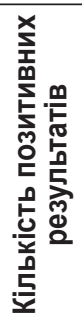 & 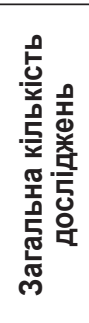 & 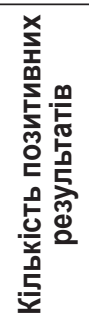 & 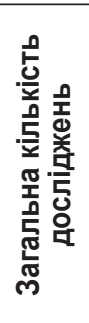 & 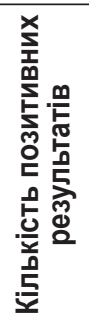 & 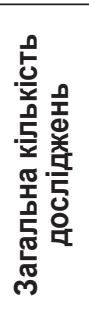 & 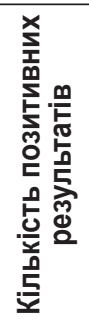 & 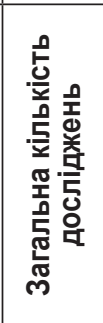 & 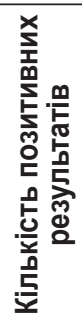 & 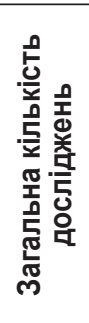 & 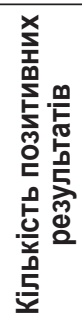 & 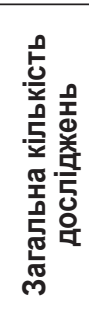 & 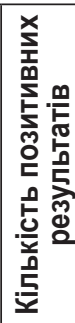 \\
\hline Важкі метали & 3 & 0 & 2 & 0 & 1 & 0 & 1 & 1 & 6 & 0 & 0 & 0 & 8 & 2 \\
\hline Пестициди & 72 & 64 & 1440 & 24 & 103 & 14 & 479 & 61 & 416 & 16 & 15 & 3 & 94 & 6 \\
\hline Мікотоксини & $2691^{*}$ & 0 & 6455 & 0 & 4664 & 0 & 5392 & 0 & 13944 & 8 & 7199 & 1 & 4960 & 3 \\
\hline $\begin{array}{c}\text { Ветеринарні } \\
\text { препарати }\end{array}$ & 8 & 5 & 13 & 13 & 3 & 3 & 13 & 7 & 9 & 3 & 13 & 6 & 7 & 5 \\
\hline Всього & 2774 & 69 & 7908 & 37 & 4770 & 17 & 5885 & 69 & 14375 & 27 & 7227 & 10 & 5069 & 16 \\
\hline
\end{tabular}

Примітка: * - показники отримані з 04.01. по 31.10.2021 p. 


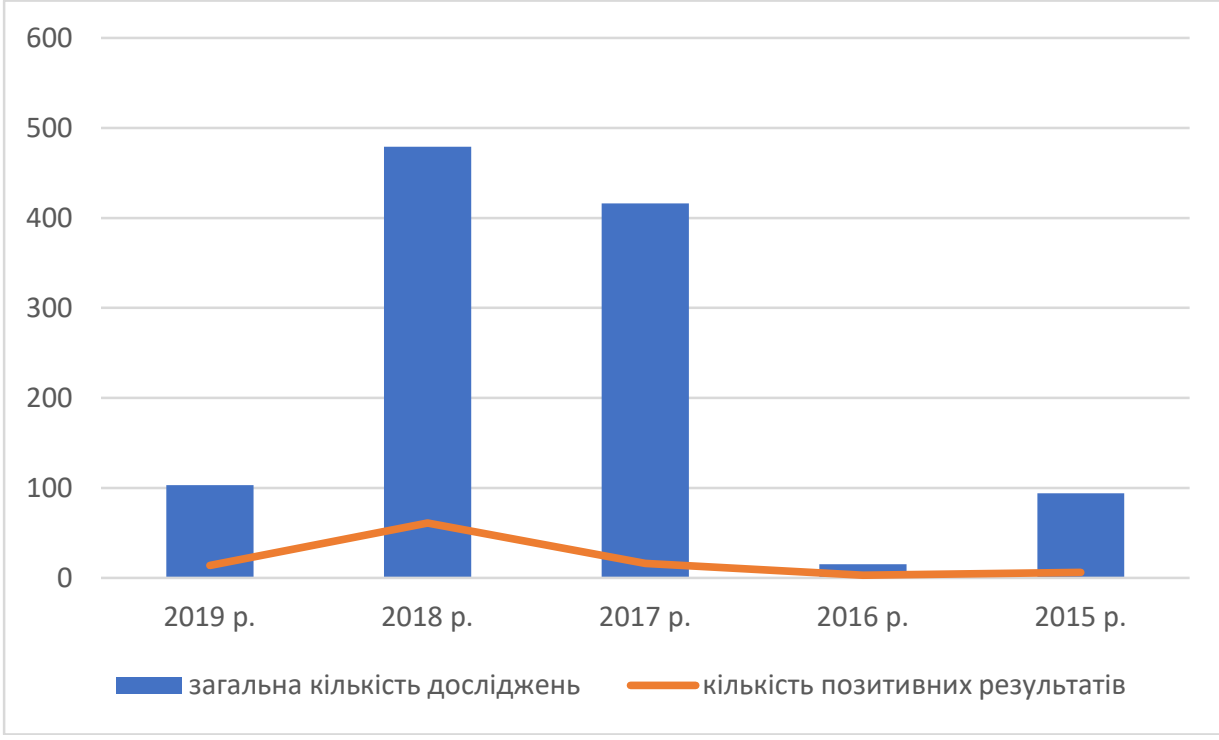

Рис. 1. Статистичний аналіз досліджень умісту пестицидів у ветеринарних об'єктах

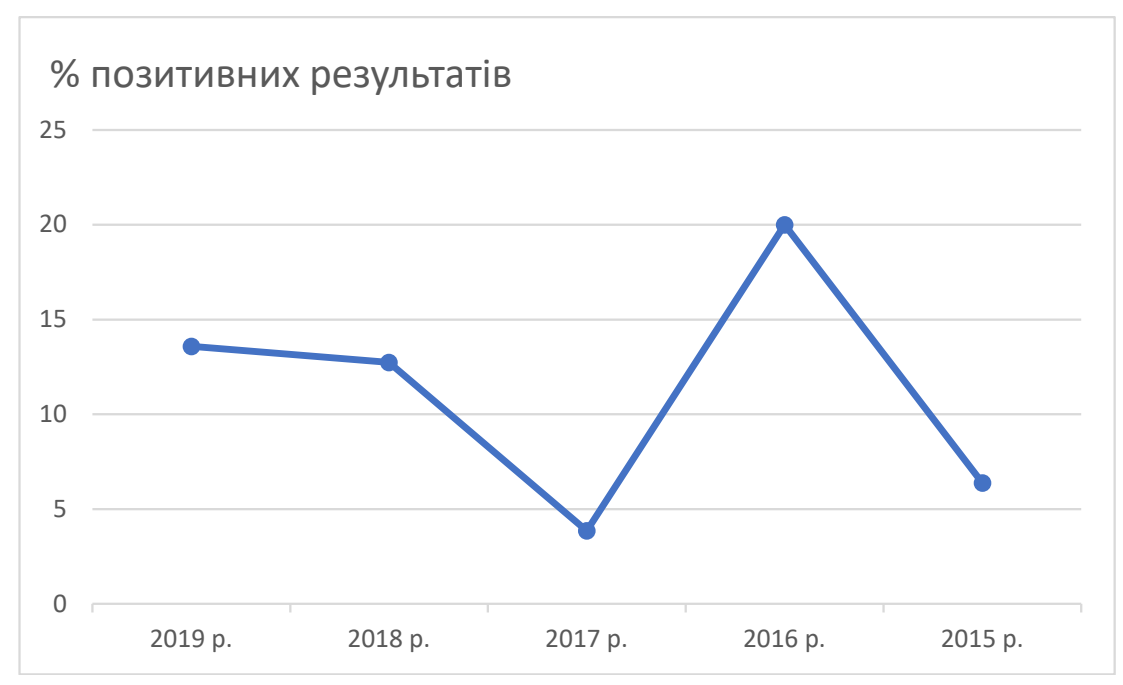

Рис. 2. Частка позитивних результатів дослідження вмісту пестицидів у ветеринарних об'єктах

Вони контамінують кукурудзу, пшеницю, ячмінь, овес, а також соєвий і соняшниковий шроти та макуху. Внаслідок дослідження встановлено, що кукурудза порівняно з іншими злаковими частіше вражається мікроміцетами роду Aspergillus flavus та Fusarium. Найчастіше у кормах ми виявляли такі мікотоксини: дезоксиніваленол, Т-2 токсин і зеараленон, рідше - афлатоксини. А от у горіхах, зокрема в арахісі, виявляли афлатоксини.

У період з 2015 по 2021 рр. проведено 42614 досліджень кормів, із них отримано 13 позитивних результатів. Ураховуючи таку невелику частку кормів, які містили мікотоксини, слід зауважити, що на випробування надходили свіжі корми, які переважно відправлялися на експорт або ті, що імпортувалися в Україну.

Серед ветеринарних препаратів ми визначали ізоніазид, який становить небезпеку для отруєння собак. За результатами наших досліджень, представлених у табл. 1 і рис. 3, добре видно значну частку позитивних результатів із виявлення ізоніазиду у шлунку отруєних собак. У 2019 і 2020 роках кількість отруєнь ізоніазидом досягала $100 \%$.

Обговорення. Ареал поширення токсичних речовин у біогеоценозі $є$ дуже широким. Небезпека токсикантів для екосистеми не обмежується лише впливом на тварин і людину, а охоплює ще й комах, рослини, бактерії і віруси. Завдяки кумулятивним властивостям екотоксиканти накопичуються у повітрі, ґрунті, водоймах, флорі і фрауні (Balali-Mood et al., 2021; Islam et al., 2007).

Системне застосування сучасних агрохімікатів і добрив (як органічних, так і мінеральних) супроводжується забрудненням ґрунтів, поверхневих і ґрунтових вод важкими металами, зокрема миш'яком (Nicholson et al., 1999). Ураховуючи повільне виведення важких металів із ґрунту, їхня концентрація із часом може сягати 


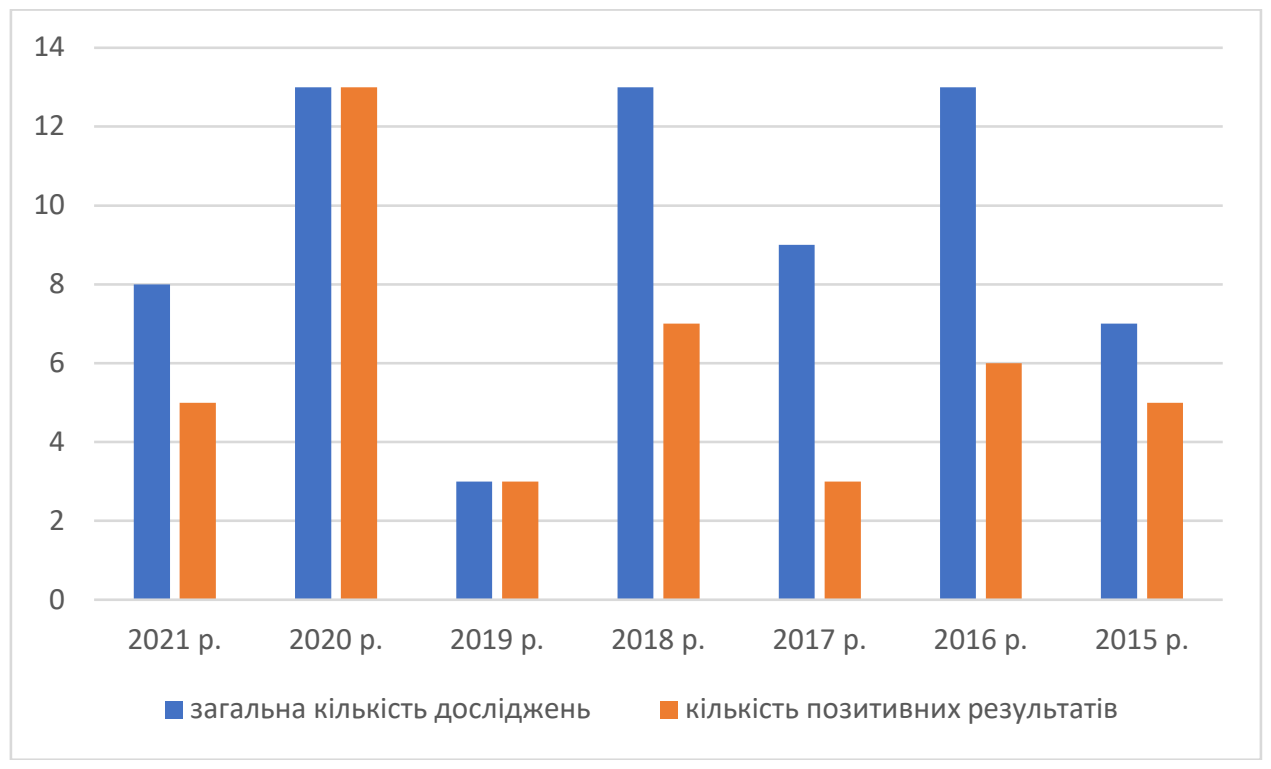

Рис. 3. Статистичний аналіз дослідження вмісту ізоніазиду у шлунку собак

високих рівнів, що призводить до надходження токсичних елементів до рослин та організму тварин (Dai et al., 2016; Zhou et al., 2020).

Основну загрозу для біосистеми з боку важких металів несуть свинець, кадмій, ртуть і миш'як. Найчастіше отруєння тварин неорганічними сполуками спричинює миш'як, що підтверджується результатами нашого дослідження. Тварини піддаються його дії головним чином через вживання корму та води. Гостра інтоксикація - основна форма отруєння миш'яком (Mandal, 2017; Selby et al., 1977).

Ми зареєстрували позитивний результат щодо вмісту миш'яку у патологічному матеріалі черепахи у 2015 році, що може свідчити про надходження цього токсичного елемента в організм черепахи разом із кормом, таким як креветки або молюски, виловлені у несприятливих екологічних умовах. Окрім того, науково підтверджено наявність арсену у борошні із комах (Biancarosa et al., 2019).

У 2018 році встановлений позитивний результат випробувань за вмістом арсену у патологічному матеріалі кошеня. Відомо, що основним джерелом забруднення екосистеми арсеном і наслідком кормів є промислові викиди (Balali-Mood et al., 2021; Wu et al., 2021). Слід також зазначити, що для кішок дуже небезпечні отрути, якими труять гризунів, зокрема миш'як. А випадки поїдання котами отруєних гризунів трапляються досить часто.

Визначення вмісту пестицидів у меді має важливе значення, оскільки їх використання за останні десятиріччя значно збільшилося через зростання попиту на виробництво продуктів харчування (Souza et al., 2016).

Висока стійкість пестицидів до розпаду є важливою передумовою їх міграції за профілем ґрунту, а також у суміжні середовища (рослини, повітря, воду), що становить небезпеку для природних біогеоценозів і, відповідно, існування людини (Socorro et al., 2016; ChiaiaHernandez et al., 2017). Тому екологічно важливим $€$ аналіз забруднення ґрунту залишками пестицидів. Ми визначили вміст пестицидів не тільки у продуктах бджільництва, загиблих бджолах, але і в зеленій масі та ґрунті.

Нами досліджувалися гербіциди, фунгіциди та інсектициди. Слід зауважити, що самі по собі фунгіциди і гербіциди не $є$ токсичними для комах, зокрема для бджіл, тільки у поєднанні з інсектицидами вони здатні спричинювати отруєння і загибель бджіл, про що свідчать результати нашого дослідження. Літературні джерела також підтверджують той факт, що одночасне застосування окремих пестицидів взаємно підсилює токсикологічний синергізм (Zhu et al., 2018)

Медоносні бджоли, як і інші запилювачі рослин, збирають нектар і пилок, через це піддаються дії широкого спектру фрітохімічних речовин. Скорочення популяції корисних комах і бджіл викликає занепокоєння із приводу нестачі запилювачів сільськогосподарських культур (Heard et al., 2017; Johnson et al., 2010; Pettis et al., 2013).

Значна частка досліджуваних нами проб загиблих бджіл, ґрунту, зеленої маси, в яких виявлені пестициди, свідчить про гостроту проблеми їх поширення і потребу у вивченні токсичності цих ксенобіотиків. Про важливість вивчення не тільки летальних, але і сублетальних доз інсектицидів на організм корисних комах говорять науковці всього світу. Сублетальні дози інсектицидів негативно впливають на здоров'я бджолиних сімей, знижуючи їх опірність до патогенних мікроорганізмів (Desneux et al., 2007; Ardalani et al., 2021).

Існують відомості про те, що у майбутньому використання у бджільництві медоносних рослин, багатих на фрлавоноїди, може захистити бджіл від впливу пестицидів (Ardalani et al., 2021).

Проблема мікотоксикозів відома понад 90 років. Як свідчить практика, мікотоксини у кормах далеко не є рідкістю. Навпаки, динаміка контамінації кормів мікотоксинами зростає і завдає значних економічних збитків, що викликає все більше занепокоєння у виробників продукції тваринництва. 
Серед свіжих кормів, досліджуваних нами, встановлена невелика частка кормів, контамінованих мікотоксинами. Як відомо, розвиток мікроміцетів у кормах і харчових продуктах не завжди є результатом антропогенної діяльності, а частково залежить від природно-кліматичних умов та умов зберігання (Gruber-Dorninger et al., 2019; Paterson \& Lima, 2010; Battilani et al., 2016). Існує висока ймовірність накопичення мікотоксинів у кормах навесні. Саме в цей період року у деяких господарствах виникає десіцит кормів, тому вони нехтують їхньою якістю, що дуже негативно позначається на здоров"ї і продуктивності тварин.

Унаслідок дослідження науковцями кормів, зібраних у 100 країнах світу, встановлено, що більше половини кормів містила хоча б один мікотоксин. Найчастіше виявляли комбінації дезоксиніваленола, зеараленона і фумонізина, а також фумонізина та афлатоксина. Найчастіше контамінувалася кукуруза, що прослідковується і в наших випробуваннях (Gruber-Dorninger et al., 2019).

Зважаючи на кумулятивний характер мікотоксинів, можна зробити висновок про те, що за постійного їх надходження до організму тварин і людини (навіть у відносно невеликих кількостях) їхня концентрація може досягти критичних рівнів і спричинити хворобу або навіть смерть. Слід ураховувати той фракт, що мікотоксини здатні посилювати токсичність один одного за рахунок синергізму. Кінцевий результат такої небезпечної синергічної дії на організм живих істот $€$ непередбачуваним, оскільки залежить не лише від поєднання різних видів мікотоксинів, але і від їхньої концентрації (Монастырский \& Искендеров, 2016).

Результати нашого дослідження, спрямовані на виявлення ізоніазиду у шлунку собак, корелюють із раніше проведеними дослідженнями. Зокрема, у 2016-2017 рр. у 41\% загиблих унаслідок невідомих причин собак установлено отруєння ізоніазидом (Bayer et al., 2018).

Окрім того, трапляються випадки отруєння кішок, але рідше, оскільки вони більш вибагливі до корму порів- няно із собаками. Останні підбирають навмисне отруєну поживу на вулиці та стають жертвами догхантерів. Висока чутливість організму собак до ізоніазиду зумовлена генетично і пов'язана зі зниженою активністю ферменту $\mathrm{N}$-ацетилтрансферази. Це, у свою чергу, не дозволяє ефективно метаболізувати у печінці $\mathrm{N}$-ацетилізоніазид, який проявляє гепатотоксичну дію на організм. Окрім того, ізоніазид $€$ антагоністом піридоксину, що спричинює його нейротоксичну дію. Утворення комплексу ізоніазид-піридоксин призводить до гальмування утворення коферментної фрорми вітаміну $\mathrm{B}_{6}$. I, як результат, знижується синтез гама-аміномасляної кислоти, яка $€$ гальмівним нейромедіатором центральної нервової системи, а також бере участь у процесах забезпечення мозку енергією та киснем. Нестача гама-аміномасляної кислоти призводить до пригнічення, слабкості, атаксії, судом і загибелі собак (Kotsiumbas \& Vretsona (2019); Frank et al., 2002)..

Отже, розширення масштабів синтезу і виробництва різних небезпечних хімічних сполук спричинює контамінацію ними кормів і продуктів харчування. Перед науковцями постало питання розроблення системного підходу до вирішення проблеми захисту здоров'я людей і біоти загалом від дії токсикантів хімічної і біологічної природи.

Висновки. Проблема поширення токсичних речовин у тваринництві і довкіллі все ще є однією із пріоритетних аграрно-продовольчих проблем у світі. Токсичне навантаження на екосистему призводить до порушення безпеки харчового ланцюга і зниження ефективності виробництва продукції тваринництва. Контамінація токсикантами кормів, а також медоносних рослин становить загрозу не тільки для сільськогосподарських тварин і корисних комах, але і для споживачів тваринницької продукції. Тому на національному і міжнародному рівнях дуже важливим є мінімізація ризиків техногенного впливу на екосистему. Одним із вирішальних заходів із гарантування продовольчої безпеки країни є ефективний контроль за виробництвом та імпортом безпечних кормів і харчових продуктів.

\section{Бібліографічні посилання:}

1. Ardalani, H., Vidkjær, N. H., Kryger, P., Fiehn, O., \& Fomsgaard, I. S. (2021). Metabolomics unveils the influence of dietary phytochemicals on residual pesticide concentrations in honey bees. Environment International, 152. https://doi. org/10.1016/j.envint.2021.106503

2. Balali-Mood, M., Naseri, K., Tahergorabi, Z., Khazdair, M. R., \& Sadeghi, M. (2021, April 13). Toxic Mechanisms of Five Heavy Metals: Mercury, Lead, Chromium, Cadmium, and Arsenic. Frontiers in Pharmacology. Frontiers Media S.A. https://doi.org/10.3389/fphar.2021.643972

3. Battilani, P., Toscano, P., Van Der Fels-Klerx, H. J., Moretti, A., Camardo Leggieri, M., Brera, C., ... Robinson, T. (2016). Aflatoxin B 1 contamination in maize in Europe increases due to climate change. Scientific Reports, 6. https://doi.org/10.1038/srep24328

4. Bayer, V., Bondarets, O.V., Dobrozhan, Yu.V., Liniichyuk, N.V., Stupak, O.M., Dereviaga, G.I., Shevchenko, L.V., Mykhalska, V.M. (2018). Diagnosis of isoniazid poisoning in dogs. Ukrainian Journal of Ecology, 8(1).

5. Biancarosa, I., Sele, V., Belghit, I., Ørnsrud, R., Lock, E. J., \& Amlund, H. (2019). Replacing fish meal with insect meal in the diet of Atlantic salmon (Salmo salar) does not impact the amount of contaminants in the feed and it lowers accumulation of arsenic in the fillet. Food Additives and Contaminants - Part A Chemistry, Analysis, Control, Exposure and Risk Assessment, 36(8), 1191-1205. https://doi.org/10.1080/19440049.2019.1619938

6. Chiaia-Hernandez, A. C., Keller, A., Wächter, D., Steinlin, C., Camenzuli, L., Hollender, J., \& Krauss, M. (2017). Long-Term Persistence of Pesticides and TPs in Archived Agricultural Soil Samples and Comparison with Pesticide Application. Environmental Science and Technology, 51(18), 10642-10651. https://doi.org/10.1021/acs.est.7b02529 
7. Conte, G., Fontanelli, M., Galli, F., Cotrozzi, L., Pagni, L., \& Pellegrini, E. (2020, August 1). Mycotoxins in feed and food and the role of ozone in their detoxification and degradation: An update. Toxins. MDPI AG. https://doi.org/10.3390/ toxins 12080486

8. Dai, S. Y., Jones, B., Lee, K.-M., Li, W., Post, L., \& Herrman, T. J. (2016). Heavy Metal Contamination of Animal Feed in Texas. Journal of Regulatory Science, 1, 21-32.

9. Desneux, N., Decourtye, A., \& Delpuech, J. M. (2007). The sublethal effects of pesticides on beneficial arthropods. Annual Review of Entomology. https://doi.org/10.1146/annurev.ento.52.110405.091440

10. El-Nahhal, Y. (2020, November 1). Pesticide residues in honey and their potential reproductive toxicity. Science of the Total Environment. Elsevier B.V. https://doi.org/10.1016/j.scitotenv.2020.139953

11. Frank, I., Lahav, D., Aroch, I. (2002). Myocardial necrosis and severe metabolic acidosis associated with isoniazid poisoning in a dog. Vet Rec., 151(21), 638-639.

12. Gruber-Dorninger, C., Jenkins, T., \& Schatzmayr, G. (2019). Global mycotoxin occurrence in feed: A ten-year survey. Toxins, 11(7). https://doi.org/10.3390/toxins11070375

13. Haburjak, J.J, Spangler, W.L. (2002). Isoniazid-induced seizures with secondary rhabdomyolysis and associated acute renal failure in a dog. J Sm Anim Pract, 43, 182-186.

14. Heard, M. S., Baas, J., Dorne, J. L., Lahive, E., Robinson, A. G., Rortais, A., ... Hesketh, H. (2017). Comparative toxicity of pesticides and environmental contaminants in bees: Are honey bees a useful proxy for wild bee species? Science of the Total Environment, 578, 357-365. https://doi.org/10.1016/j.scitotenv.2016.10.180

15. Islam, E. ul, Yang, X. e., He, Z. li, \& Mahmood, Q. (2007). Assessing potential dietary toxicity of heavy metals in selected vegetables and food crops. Journal of Zhejiang University. Science. https://doi.org/10.1631/jzus.2007.B0001

16. Johnson, R. M., Ellis, M. D., Mullin, C. A., \& Frazier, M. (2010, May). Pesticides and honey bee toxicity - USA. Apidologie. https://doi.org/10.1051/apido/2010018

17. Kotsiumbas, H. I., \& Vretsona, N. P. (2019). Morphofunctional changes in the heart and lung tissues of dogs for isoniazid poisoning. Ukrainian Journal of Veterinary and Agricultural Sciences, 2(2), 12-17. https://doi.org/10.32718/ujvas2-2.03

18. Mandal, P. (2017, March 1). An insight of environmental contamination of arsenic on animal health. Emerging Contaminants. KeAi Communications Co. https://doi.org/10.1016/j.emcon.2017.01.004

19. Monastyrskij, O.A., Iskenderov, M.YA. (2016).Mikotoksiny - globalnaya problema bezopasnosti produktov pitaniya i kormov. Agrohimiya, 6, 67-71.

20. More, A. F., Spaulding, N. E., Bohleber, P., Handley, M. J., Hoffmann, H., Korotkikh, E. V., ... Mayewski, P. A. (2017). Next-generation ice core technology reveals true minimum natural levels of lead $(\mathrm{Pb})$ in the atmosphere: Insights from the Black Death. GeoHealth, 1(4), 211-219. https://doi.org/10.1002/2017GH000064

21. Mulware, S. J. (2020). Toxicity of Heavy Metals, A. Subject in Review. International Journal of Recent Research in Physics and Chemical Sciences, 6(2), 30-43.

22. Nicholson, F. A., Chambers, B. J., Williams, J. R., \& Unwin, R. J. (1999). Heavy metal contents of livestock feeds and animal manures in England and Wales. Bioresource Technology, 70(1), 23-31. https://doi.org/10.1016/ S0960-8524(99)00017-6

23. Paterson, R. R. M., \& Lima, N. (2010). How will climate change affect mycotoxins in food? Food Research International, 43(7), 1902-1914. https://doi.org/10.1016/j.foodres.2009.07.010

24. Pettis, J. S., Lichtenberg, E. M., Andree, M., Stitzinger, J., Rose, R., \& vanEngelsdorp, D. (2013). Crop Pollination Exposes Honey Bees to Pesticides Which Alters Their Susceptibility to the Gut Pathogen Nosema ceranae. PLoS ONE, 8(7). https://doi.org/10.1371/journal.pone.0070182

25. Selby, L. A., Case, A. A., Osweiler, G. D., \& Hayes, H. M. (1977). Epidemiology and toxicology of arsenic poisoning in domestic animals. Environmental Health Perspectives, 19, 183-189. https://doi.org/10.1289/ehp.7719183

26. Socorro, J., Durand, A., Temime-Roussel, B., Gligorovski, S., Wortham, H., \& Quivet, E. (2016). The persistence of pesticides in atmospheric particulate phase: An emerging air quality issue. Scientific Reports, 6. https://doi.org/10.1038/ srep33456

27. Souza Tette, P. A., Guidi, L. R., De Abreu Glória, M. B., \& Fernandes, C. (2016, March 1). Pesticides in honey: A review on chromatographic analytical methods. Talanta. Elsevier B.V. https://doi.org/10.1016/j.talanta.2015.11.045

28. Todorovic T., Vujanovic D., Dozic I. (2008). Calcium and magnesium content in hard tissues of rats under condition of subchronic lead intoxication. Magnesium Research. 21(1), 43-50.

29. Wu, Q., Hu, W., Wang, H., Liu, P., Wang, X., \& Huang, B. (2021). Spatial distribution, ecological risk and sources of heavy metals in soils from a typical economic development area, Southeastern China. Science of the Total Environment, 780. https://doi.org/10.1016/j.scitotenv.2021.146557

30. Yang, C., Song, G., \& Lim, W. (2020, May 5). Effects of mycotoxin-contaminated feed on farm animals. Journal of Hazardous Materials. Elsevier B.V. https://doi.org/10.1016/j.jhazmat.2020.122087

31. Zhou, J., Du, B., Liu, H., Cui, H., Zhang, W., Fan, X., Zhou, J. (2020). The bioavailability and contribution of the newly deposited heavy metals (copper and lead) from atmosphere to rice (Oryza sativa L.). Journal of Hazardous Materials, 384. https://doi.org/10.1016/j.jhazmat.2019.121285

32. Zhu, J., Wang, J., Ding, Y., Liu, B., \& Xiao, W. (2018). A systems-level approach for investigating organophosphorus pesticide toxicity. Ecotoxicology and Environmental Safety, 149, 26-35. https://doi.org/10.1016/j.ecoenv.2017.10.066 
Chechet O. M., Phd, State Research Institute for Laboratory Diagnostics and Veterinary Sanitary Examination, Kyiv, Ukraine Shulyak S. V., Phd, State Research Institute for Laboratory Diagnostics and Veterinary Sanitary Examination, Kyiv, Ukraine

Kobish F. I., Phd, State Research Institute for Laboratory Diagnostics and Veterinary Sanitary Examination, Kyiv, Ukraine

Omelchun Yu. A., State Research Institute for Laboratory Diagnostics and Veterinary Sanitary Examination, Kyiv, Ukraine

Myagka K. S., Phd, State Research Institute for Laboratory Diagnostics and Veterinary Sanitary Examination, Kyiv, Ukraine

Marchenko T. V., State Research Institute for Laboratory Diagnostics and Veterinary Sanitary Examination, Kyiv, Ukraine

Liniychuk N. V., Phd, State Research Institute for Laboratory Diagnostics and Veterinary Sanitary Examination, Kyiv, Ukraine The problem of the distribution of toxicants in livestock and the environment

Significant expansion of the scale of synthesis and application of various dangerous chemical compounds in agriculture causes daily dangerous effects on the body of insects, animals and, of course, humans. That is why there is a need to control the spread of chemical and biological toxicants in livestock and the environment. We analyzed the distribution of toxicants in livestock and the environment by chemical and toxicological analysis of feed, manure, blood, internal organs, stomach contents of animals killed by poisoning, as well as dead bees, soil, green mass and bee products. Modern research methods were used in the work. Heavy metals were determined by atomic absorption spectrometry. Pesticides - by gas chromatography and liquid chromato-mass spectrometry. Mycotoxins - by high performance liquid chromatography, enzymelinked immunosorbent assay and thin layer chromatography. Isoniazid was examined in the stomach of dogs by liquid chromatography with a mass spectrometric detector. Analysis of heavy metals in the pathological material of dead animals showed that food poisoning of animals with arsenic is more common. In addition, a significant proportion of isoniazid poisoning of dogs has been reported. It has been established that beekeeping products are often contaminated with pesticides. It has been studied that maize is more often affected by micromycetes of the genus Aspergillus flavus and Fuzarium than other cereals. In the feed we most often found the following mycotoxins: deoxynivalenol, T-2 toxin and zearalenone, less often aflatoxins. Thus, the toxic load on the ecosystem leads to disruption of food chain safety and reduced efficiency of livestock production. Contamination of food and honey plants with toxicants poses a threat not only to farm animals and beneficial insects, but also to consumers of livestock products. Therefore, at the national and international levels, effective control over the production and import of safe feed and food is very important.

Key words: toxicants, heavy metals, pesticides, mycotoxins, isoniazid, ecosystem, animal poisoning, feed, beekeeping products. 